\title{
Characterization of Physical and Chemical Properties of Effervescent Tablets Temulawak (Curcuma zanthorrhiza) in the Various Proportion of Sodium Bicarbonate and Tartaric Acid
}

\author{
Herlina $^{1, *}$, Nita Kuswardhani $^{1}$, Maria Belgis ${ }^{1}$, Adinda Tiara $^{1}$ \\ ${ }^{1}$ The University of Jember, Faculty of Agricultural Technology, Department of Agricultural Product Technology, \\ Kalimantan street. No. 37 Post Code No. 68121 Jember, East Java, Indonesia.
}

\begin{abstract}
The purpose of this study was to determine the effect of comparative treatment of the proportion of Sodium bicarbonate and tartaric acid on the physical and chemical properties of effervescent tablets temulawak, as well as knowing the proportions of sodium bicarbonate and tartaric acid right to produce a good effervescent tablets temulawak. The research method uses a single completely randomized design namely the ratio of sodium bicarbonate: tartaric acid, $(\mathrm{F} 1=2.0: 2.5 ; \mathrm{F} 2=2.5: 2.0 ; \mathrm{F} 3=3.0 ; 1.3 ; \mathrm{F} 4=3,5$ : 1,0 , and F5 $=4.0: 0.5 \mathrm{y}$ ). each treatment was repeated 3 (three) times. The resulted data were analyzed by ANOVA test. The results showed that the proportion of sodium bicarbonate and tartaric acid significantly affected color lightness, hardness, hygroscopicity, solubility times, water content, ash content, and not significantly affect viscosity and $\mathrm{pH}$. The right proportion of sodium bicarbonate acid tartaric acid for making effervescent tablets temulawak is A1 treatment (proportion of sodium bicarbonate and tartaric acid 2.0: 2.5) with the attributes of water content of $66.72 \%$, hardness of $2.20 \mathrm{~kg}$, hygroscopicity of $25.43 \mathrm{~g}$, solubility times of 35 seconds, viscosity $1.75 \mathrm{MPa} . \mathrm{S}$, water content $1.19 \%$, ash content $3.10 \%$, and $\mathrm{pH}=5.1$.
\end{abstract}

Keywords: effervescent tablets temulawak, physical properties, chemical properties, solubility times, hygroscopicity.

\section{INTRODUCTION}

Temulawak is a plant that grows in clumps, which has long been known and used by some Indonesian people, both as traditional medicine, a coloring agent, or as food. Temulawak consists of curcuminoids and essential oils. Curcuminoids from temulawak consist of two compounds namely curcumin and demethoxycurcumin. Curcumin as one of the compounds in the curcuminoid fraction has antioxidant activity [4,8], anti-cancer, anti-inflammatory, antitumor, and hypocholesterolemia. Essential oils from temulawak consist of 32 components[9]. Temulawak products that have been on the market in the form of herbs, emulsions, syrups, temulawak capsules and local drinks typical of the Banyuwangi region are carbonated temulawak juice drinks. In general, people still associate temulawak as herbal medicine that has a bitter taste and a bad odor, even though if consumed regularly it can maintain and improve health. Therefore, there must be a new paradigm that consuming temulawak drink is not always synonymous with bitter, smelly and impractical taste. However, it can be made practical in the form of tablets that can be immediately dissolved in water namely effervescent tablets temulawak. Effervescent tablets can increase aesthetics and pleasure for consumers when they are going to drink it, and to mask the taste of active ingredients from temulawak, curcuminoids which have a slightly bitter taste, making it easier for people to consume them. Effervescent preparations are more practical, easy to use, and more pleasing when compared to other forms.

The sources of organic acids used in this study were citric acid and tartaric acid and the base source chosen was sodium bicarbonate so that it was expected to mask the bitter taste of temulawak plant extracts. Citric acid has several advantages over other sources of acid, which are very soluble in water, and gives an acidic taste to effervescent tablets. Another source of acid is tartaric acid. Effervescent salts are usually processed from a combination of citric and tartaric acid, because the use of only one single acid will cause difficulties. If tartaric acid is a single acid, the resulting granules will easily lose their strength and will clot. Citric acid alone will produce a mixture of sticky and difficult to be granules [1,2,11]. Meanwhile, if the citric acid combined with tartaric acid can strengthen bonds between particles in the effervescent tablet, so that it can produce the hardness of a good tablet, where the tablets are resistant to shocks and friction during compression, packaging, and distribution. Sodium bicarbonate is the main source of carbon dioxide in the effervescent system. This compound is completely soluble in water, not hygroscopic, inexpensive, widely available on the market, can be eaten and widely used in food products as baking soda, and gives a fresh taste like soda water[5]. The presence of gas from sodium bicarbonate will mask the bitter taste and simplify the dissolution process without involving manual stirring, provided that all its components are very soluble in water. Sodium bicarbonate is the weakest sodium alkali, having a $\mathrm{pH}$ of 8.3 in aqueous solution in a

\footnotetext{
"Corresponding author: lina.ftp@unej.ac.id
} 
concentration of $0.85 \%$. This substance produces about $52 \%$ of carbon dioxide [22].

This effervescent tablet is a development of the temulawak fizzy drinks typical of the Banyuwangi area. Effervescent tablet preparations are influenced by solubility, taste, texture, effervescent quality, however, until now there has been no information on how to make effervescent tablets temulawak with a proportion of sodium bicarbonate and tartaric acid, so research on the proportions of effervescent tablets of temulawak drink is needed. with a combination of sodium bicarbonate and tartaric acid to produce quality effervescent tablets temulawak

\section{MATERIAL AND METHODS}

\subsection{Research Tools and Materials}

The tools used in the study were single punch tablet presses (Shanghai Tianhe Pharmaceutical Machinery), ovens (Memmert), furnaces / muffles / furnaces, desiccators, viscometer ndj-8s, maceration tools (soaking vessels, stirrers, and filters), blender, analytical balance, $\mathrm{Cr}-10$ color reader, beaker glass, stopwatch, 60 mesh sieve, Monsanto hardness tester (Global Quality), tablet friability tester, weighing bottle, exchange rate, Crucible tangs, $\mathrm{pH}$ meter. Raw materials used are temulawak obtained from the market, xylitol (nourish), sodium bicarbonate (T\&T Chemical), citric acid (anhydrous), tartaric acid (Asian), PVP K-30.

\subsection{Trial Design}

This study used a Completely Randomized Design with five variations in the proportions of sodium bicarbonate and tartaric acid that were different $(\mathrm{F} 1=2.0: 2.5 ; \mathrm{F} 2=2.5: 2.0 ; \mathrm{F} 3=3.0 ; 1.3 ; \mathrm{F} 4=3.5$ : 1.0 , and F5 $=4.0: 0.5$ ), each sample was repeated 3 times.

\subsection{Making Effervescent Tablets temulawak}

Prepare of sodium bicarbonate, citric acid, tartaric acid, xylitol, and PVP. Each material is weighed according to the tablet formulation to be made, namely the proportion of sodium bicarbonate: tartaric acid (F1 = $2.0: 2.5 ; \mathrm{F} 2=2.5: 2.0 ; \mathrm{F} 3=3.0 ; 1.3 ; \mathrm{F} 4=3.5: 1.0$, and $\mathrm{F} 5=4.0: 0.5$ ), add to each treatment $4 \mathrm{~g}$ instant temulawak, citric acid 1g, xylitol 8g, PVP $0.165 \mathrm{~g}$. Furthermore, mixing and effervescent granules are produced. Effervescent granules were obtained each weighed as much as $3 \mathrm{~g}$ and printed on a tablet machine. In making effervescent tablets things that must be considered are how to determine the right formula so that the resulting preparations can produce effective froth, stable tablets and produce a comfortable product. The difficulty in making effervescent tablets is controlling the humidity of the room used for making tablets. Moisture is related to the stability of the effervescent tablets produced. The higher the humidity, the more difficult it is tableting because with high humidity the acid-base in the tablets will react more quickly so that the resulting tablets will become soft more quickly, for that $40 \%$ relative humidity must be maintained.

\subsection{Physical and Chemical Tests}

\subsubsection{Color Lightness}

Physical test for color parameters on this effervescent tablet uses a Cr-10 Color reader. The workings of this tool are affixed to the sample, which will be tested for color lightness, then the test button is pressed until it sounds or the light is on and will appear in the form of numbers and then measured on the graph to find out the color specifications. The working principle of a color reader is a color exposure system using a CIE system with three color receptors namely $\mathrm{L}$, a, b Hunter. The L symbol shows the lightness level based on white, the symbol indicates reddish or greenish, and symbol B indicates yellowish or bluish[24].

\subsubsection{Hardness [3]}

Hardness is a parameter that describes the resistance of the tablet against mechanical problems such as shaking, scraping and cracking of the tablet during wrapping, transporting, using. This hardness is used as a measure of compression pressure. Factors that influence tablet hardness are compression pressure and the nature of the felt material. The hardness test is carried out one by one with hardness tester. The permissible hardness of tablets is between 4 to $8 \mathrm{~kg}$. One tablet is placed in the middle and perpendicular to the hardness tester, first scales at zero position, then the device is turned slowly until the tablet breaks. Read the scale achieved when the tablet is broken or destroyed.

\subsubsection{Solubility Time[21]}

The solubility time of the tablet is defined as the time needed to dissolve the tablet in a suitable so that no tablet part is left above the cash. Tablets undergo disaggregation (loss of granular cohesion) to release the drug which results in the dispersion of constituent components in fine particles[25]. A good effervescent tablet has a dissolution time of no more than 1 minute. Solubility is measured by calculating the dissolution time needed by a tablet for a serving size of one fruit using a $500 \mathrm{ml}$ measuring cup. Tablets that will be measured at the dissolution time, put in $200 \mathrm{ml}$ of water in a measuring cup together with the start of the calculation using a stopwatch.

\subsubsection{Viscosity[23]}

Viscosity is a measure of the thickness of a fluid which shows the size of the fluid's internal friction. Viscosity on effervescent tablets is very important. The viscosity of a liquid indicates the speed at which it flows. The thicker a liquid, the greater the force needed to make it flow at a certain speed. The viscosity test of effervescent tablets temulawak was carried out using viscometer type VT-04 E. Viscometer type VT-04E works based on the principle of rotational resistance of the rotor by the extract being tested. The thicker the extract produced, the greater the inhibitory power of 
the extract on the rotor rotation. The shape and size of the rotor are adjusted to the extract produced so that the rotor can still rotate in the extract being tested, in this study rotor number 3 is used.

\subsection{5. water content [16]}

A sample of 3-5 grams is weighed and put into a dried cup and its weight is known. Then the sample and the cup were dried in an oven at $105^{\circ} \mathrm{C}$ for 6 hours. The cup is cooled (desiccator) and weighed, then dried again until a constant weight is obtained.

\subsubsection{Ash content [16]}

The material to be grayed is placed in a crucible made of porcelain, ashing is carried out with a muffle (furnace) of $500-600^{\circ} \mathrm{C}$, the length of ashes of each material is different, ranging from 2-8 hours. Graying is considered complete if the remaining gray graying is obtained and has a constant weight. Weighing the material is done in cold temperatures, a crucible containing ash is heated in an oven at $105^{\circ} \mathrm{C}$ to lower the crucible temperature, then put it into the desiccator.

\subsubsection{Test the $\mathrm{pH}$}

The $\mathrm{pH}$ test on this effervescent tablet uses a $\mathrm{pH}$ meter. The method for $\mathrm{pH}$ testing is done by dissolving effervescent in $200 \mathrm{~mL}$ aqua dest then the $\mathrm{pH}$ is measured using of a $\mathrm{pH}$ meter, and the measurement results are said to be good if the $\mathrm{pH}$ of the effervescent solution approaches $\mathrm{pH}=7$.

\subsection{Data Analysis}

The data obtained were tested with ANOVA (Analysis of Variance) with a 95\% confidence level or significance $(\mathrm{p} \leq 0.05)$.

\section{RESULTS AND DISCUSSION}

\subsection{Color Lightness}

Color observations were carried out to determine the color lightness of effervescent tablets temulawak products. The average value of the color lightness of effervescent tablets temulawak can be seen in Figure 1. ANOVA diversity test results showed that the proportion of sodium bicarbonate and tartaric acid in the manufacture of effervescent tablets temulawak significantly affected the color lightness of the product.

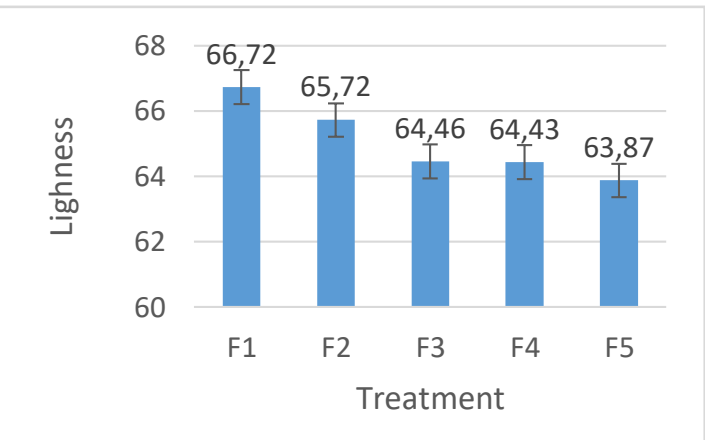

Figure 1. The average value of the color lightness of effervescent tablets temulawak
Based on Figure 1. shows that the level of color lightness ranges from 63.87 to 66.72 . From the results of these data, it can be seen that F1 has the highest level of color lightness compared to the others which are equal to 66.72. This is due to the balanced concentrations of tartaric acid and sodium bicarbonate which make the F1 lightness higher than the others. The yellow color of temulawak extract powder is caused by the curcumin content of temulawak. Because of the sodium bicarbonate powder, and the tartaric acid itself is white, therefore with more concentration added the lightness of effervescent tablets temulawak increases and the yellow color of the temulawak decreases. The white color of Na-bicarbonate powder, citric acid, and tartaric acid when added will cover the original color of lemongrass powder, the more addition of effervescent mix will cause the lighter color of effervescent lemongrass [21]. The effervescent color in this study has fulfilled the requirements for instant beverage powder color (SNI 01-4320-1996).

\subsection{Tablet Hardness}

Tablet hardness is one of the quality parameters that illustrates the resistance of the tablet to mechanical interference. The hardness of the tablet measured mechanically is used as a parameter of the physical quality of the tablet to determine the cohesiveness of the tablet after printing. Compact tablets are estimated to be able to survive during the distribution and storage process[17]. The average value of effervescent tablet temulawak hardness can be seen in Figure 2. ANOVA diversity test results showed that the proportion of sodium bicarbonate and tartaric acid in the manufacture effervescent tablets temulawak significantly affected the hardness of tablet products.

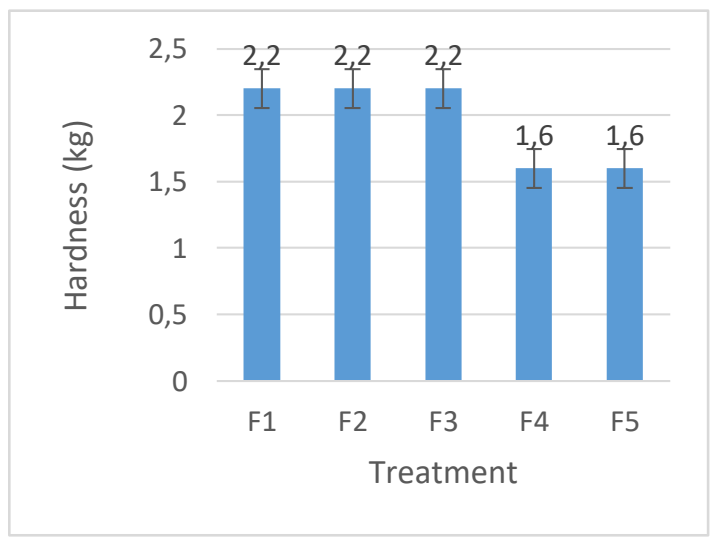

Figure 2. The average value of the hardness of effervescent tablets temulawak

Figure 2. shows that the average value of effervescent tablet temulawak hardness in various proportions of sodium bicarbonate and tartaric acid ranged from $1.6 \mathrm{~kg}$ to $2.2 \mathrm{~kg}$ whereas according to the United States Pharmacopeia (USP) the hardness requirements of a tablet ranged from 4-9 $\mathrm{kg}[17,18,19]$. Based on Figure 2 it can be seen that F1 treatment has the highest tablet hardness of $2.2 \mathrm{~kg}$ while $\mathrm{F} 5$ has the lowest tablet hardness of $1.6 \mathrm{~kg}$. This is due to the 
addition of tartaric acid, the higher the resulting tablet, the softer. This is due to the nature of the hygroscopic tartaric acid which easily absorbs water and causes the texture of the tablet to become soft, especially in rooms with high moisture content, so that the hardness of the tablet drops, conversely the greater the concentration of sodium bicarbonate the harder the tablet. The interaction between sodium bicarbonate and tartaric acid decreases hardness of effervescent tablet temulawak.

\subsection{Hygroscopicity}

Hygroscopicity is the ability of a substance to absorb moisture from the air. Hygroscopic values of effervescent tablets temulawak with variations in the proportion of sodium bicarbonate, and tartaric acid can be seen in Figure 3. ANOVA diversity test results showed that the proportion of sodium bicarbonate and tartaric acid in the manufacture of effervescent tablets temulawak significantly affected the hygroscopicity of product tablets.

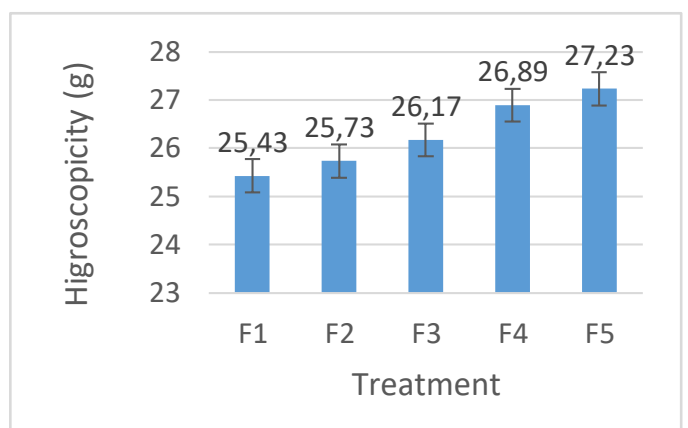

Figure 3. The average hygroscopicity value of effervescent tablets temulawak.

Figure 3. shows that the hygroscopicity value of effervescent tablets temulawak ranged from $25.43 \mathrm{~g}$ to 27.23 g. F5 treatment has the highest average hygroscopicity value that is equal to $27.23 \mathrm{~g}$. This is due to effervescent tablets which act as a destroyer and are a source of acid and carbonate. Capillary effects can be magnified in the presence of crushing agents. In addition to crushing agents, capillary effects are also influenced by tablet porosity. The amount of porosity causes more liquid to enter the tablet. Tablet porosity is influenced, among others, by the size distribution or mass of tablets and the pressure applied during the pressing process. The liquid that has entered the tablet will damage the bonds between the particles and cause the destructive material to expand which then causes the tablet to disintegrate. This expanding crushing agent can also produce a thick, sticky mass that can block the entry of liquid into the tablet to prolong the disintegration time. Therefore, it is necessary to optimize the levels of the crushing agent in tablet formula. The reaction used to dissolve effervescent tablets is the reaction between an acidic source and a carbonate source that produces gases in the form of carbon dioxide, occurring spontaneously when the tablet enters the water. Then this gas can push the tablet so that the tablet becomes destroyed and has high hygroscopicity. The reaction equation is as follows [6]:

$\mathrm{H}_{3} \mathrm{C}_{6} \mathrm{H}_{5} \mathrm{O}_{7} . \mathrm{H}_{2} \mathrm{O}+3 \mathrm{NaHCO}_{3} \rightarrow \mathrm{N}_{3} \mathrm{C}_{6} \mathrm{H}_{5} \mathrm{O}_{7}+4 \mathrm{H}_{2} \mathrm{O}+3 \mathrm{CO}_{2}$

Citric Acid $+\mathrm{Na}$-Bicarbonate $\rightarrow \mathrm{Na}$-Citrate + Water + Carbon dioxide

$\mathrm{H}_{2} \mathrm{C}_{4} \mathrm{H}_{4} \mathrm{O}_{6}+2 \mathrm{NaHCO}_{3} \rightarrow \mathrm{Na}_{2} \mathrm{C}_{4} \mathrm{H}_{4} \mathrm{O}_{6}+2 \mathrm{H}_{2} \mathrm{O}+2 \mathrm{CO}_{2}$

Tartic Acid $+\mathrm{Na}$-Bicarbonate $\rightarrow \mathrm{Na}$-Tartaric + Water + Carbon dioxide

\subsection{Solubility Times}

Measurement of the solubility times of effervescent tablets is carried out to determine the length of time needed to dissolve effervescent tablets in water. The end of effervescent solubility is marked by the dissolution of all the effervescent solid components into a solution and no more gas bubbles arise. The faster time needed to dissolve the effervescent component means that the solubility of the effervescent component is high[24]. The average value of soluble time of ginger effervescent tablets with variations in the proportion of sodium bicarbonate and tartaric acid can be seen in Figure 4. The ANOVA diversity test results showed that the proportion of sodium bicarbonate and tartaric acid in the manufacture of effervescent tablets temulawak significantly affected the solubility time of tablets products.

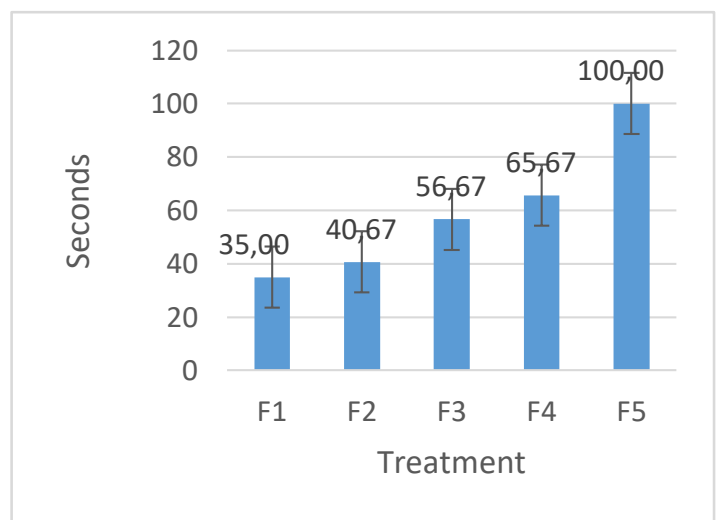

Figure 4. The average solubility times of effervescent tablets temulawak.

Figure 4. shows that the average value of solubility times in effervescent tablets temulawak with a combination of Sodium bicarbonate and tartaric acid ranges from 35 seconds to 100 seconds. F1 treatment has the fastest average dissolution time value of only 35 seconds, whereas, in F5 treatment, it has a fairly long dissolution time of 100 seconds. According to [7] good soluble effervescent powder ranges from 1-2 minutes. If the effervescent is well dispersed in water with a time of $\leq 5$ minutes, then the preparation meets the requirements of dissolution time [10]. Figure 4. shows that the test results obtained by the soluble time to 5 effervescent tablet formula have a soluble time of fewer than 2 minutes so it can be said to meet the requirements. This is consistent with the opinion of [14] which states that the higher the concentration of sodium bicarbonate added, the solubility of carbonated drinks will be faster because of sodium bicarbonate functions as a deterrent. Conversely, with the addition of higher acids in the F1 and F2 treatments have a 
longer soluble time. That the addition of acid effects on increasing the effervescent solubility time at both low and high levels of sodium bicarbonate. Effervescent tablets which are in high RH (humidity) conditions will cause the tablet to easily absorb water vapor and cause acids and bases (citric acid; tartaric acid and sodium bicarbonate) to react more easily to produce $\mathrm{CO}$. become very long[20].

\subsection{Viscosity Test}

The viscosity of a liquid indicates the speed at which it flows. The thicker a liquid, the greater the force needed to make it flow at a certain speed (Martin, 1993). The viscosity test of ginger effervescent tablets was carried out using viscometer type VT-04 E. Viscotester type VT-04E works based on the principle of rotational resistance of the rotor by the extract being tested. The thicker the extract produced, the greater the inhibitory power of the extract on the rotor rotation. The shape and size of the rotor are adjusted to the extract produced so that the rotor can still rotate in the extract being tested. In this study rotor number 3 was used.

ANOVA diversity test results showed that the proportion of sodium bicarbonate and tartaric acid in the manufacture of temulawak effervescent tablets did not significantly affect the viscosity of product tablets. This is because the interaction of sodium bicarbonate and tartaric acid does not give effect to changes in viscosity and the proportion of additions between treatments is relatively small, according to [24] the viscosity of a mixture is influenced by interactions of temperature, $\mathrm{pH}$ and concentration.

\subsection{Moisture content}

Water content is a parameter that has an important role and influences the quality stability of a product. Water content can affect the appearance of texture and food taste[12]. The results of effervescent tablet temulawak moisture content can be seen in Figure 5 . ANOVA diversity test results showed that the proportion of sodium bicarbonate and tartaric acid in the manufacture of effervescent tablets temulawak significantly affected the water content of the product tablets.

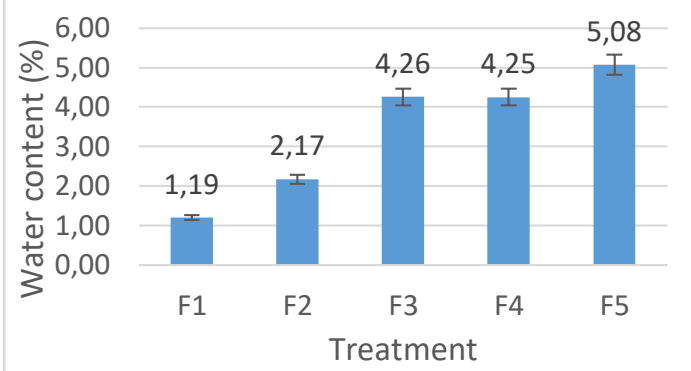

Figure 5. The average water content of effervescent tablets temulawak

Figure 5. shows that the water content of effervescent tablets temulawak ranged from $1.19 \%$ to
$5.08 \%$. The effervescent tablet moisture content produced by the requirements, because according to Juita (2008), the effervescent tablet water content requirement with a maximum of $10 \%$ herbal ingredients while the five formulations meet the requirements because each has a water content value below $10 \%$.

The F5 treatment has the highest average water content value of $05.08 \%$, while F1 has the lowest water content value of $1.19 \%$. This is because effervescent tablets consist of tartaric acid compounds, and sodium bicarbonate containing water molecules so that the higher concentrations of tartaric acid and sodium bicarbonate are added, the more water molecules in the effervescent tablet temulawak product. This is in line with the statement of [7] that tartaric acid is hygroscopic or easily absorbs water particles in the air with high humidity.

The high water content is caused when the RH tablet is quite high, so the material used in making tablets absorbs water from the environment during the mixing or printing process. According to[3] the ideal room for making effervescent tablets is $40 \%$.

\subsection{Ash Content}

The determination of ash content is closely related to the mineral content contained in a material[16]. In the combustion process, the organic material burns out but inorganic substances do not burn out, the rest of the combustion is called ash. The results of ginger effervescent tablet ash test results can be seen in Figure 6. ANOVA diversity test results showed that the proportion of sodium bicarbonate and tartaric acid in the manufacture of effervescent tablets temulawak significantly affected the ash content of tablet products.

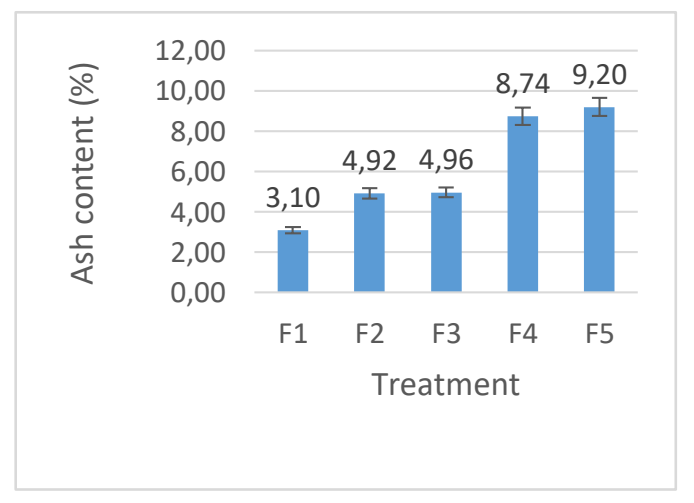

Figure 6. The average ash content values of effervescent tablets temulawak

Figure 6. shows that the value of effervescent tablet temulawak ash content ranged from $3.10 \%$ to $9.20 \%$. The F5 treatment has the highest average ash content of $9.20 \%$ compared to the others, while F1 has the lowest ash content value of $3.10 \%$. This is due to the higher concentration of tartaric acid compounds, and the added sodium bicarbonate, the effervescent tablet ash content increases. Effervescent tablet material consists of sodium bicarbonate which is an inorganic compound. The more sodium bicarbonate 
that is added causes the inorganic compound content of the material to also increase so that the ash content of the product also increases. According to [12] states that sodium bicarbonate has a mineral content of sodium bicarbonate which is high enough, so the higher the mineral of a food ingredient, the greater the ash content in that material.

\subsection{PH test}

The $\mathrm{pH}$ test needs to be done because if the effervescent solution that is formed is too acidic it can irritate the stomach while if it is too alkaline it causes a bitter and unpleasant taste[5]. The $\mathrm{pH}$ test on effervescent tablets using a $\mathrm{pH}$ meter. ANOVA diversity test results showed that the proportion of sodium bicarbonate and tartaric acid in the manufacture of Curcuma effervescent tablets did not significantly affect the $\mathrm{pH}$ of the product tablets.

The average $\mathrm{pH}$ of temulawak effervescent tablets ranged from $5.10 \%$ to $6.25 \%$. The overall $\mathrm{pH}$ of the 5 formulations fulfills the requirements of having a $\mathrm{pH}$ range of 5-6 because of the appropriate $\mathrm{pH}$ and acid balance between each formulation, Above $\mathrm{pH} 7.8$ or below pH 6.8 will cause metabolic disorders, which in finally also disruption to health. The $\mathrm{pH}$ range is acidic, because the lower $\mathrm{pH}$ value indicates the high acidity of a product. The formation of $\mathrm{CO} 2$ during the effervescent reaction in water which will partially dissolve to form carbonic acid will reduce the $\mathrm{H}+$ ions in solution, causing acidity in the solution and result in a low $\mathrm{pH}$ value [13]. Effervescent has good solubility at $\mathrm{pH}$ between 5-7 because effervescent is not stable at $\mathrm{pH}>8$. whereas according to[26] effervescent quality requirements $<6$. Effervescent $\mathrm{pH}$ must be acidic because sodium bicarbonate requires acidic reagents. In the presence of hydrogen ions provided by the acid developer, sodium bicarbonate reacts to release carbon dioxide.

\section{CONCLUSION}

The results showed that the proportion of sodium bicarbonate and tartaric acid significantly affected color lightness, hardness, hygroscopicity, solubility times, water content, ash content, and did not significantly affect viscosity and $\mathrm{pH}$. The right proportion of sodium bicarbonate acid tartaric acid for making effervescent tablets temulawak is A1 treatment (proportion of sodium bicarbonate and tartaric acid 2.0: $2.5)$ with the attributes of water content of $66.72 \%$, hardness of $2.20 \mathrm{~kg}$, hygroscopicity of $25.43 \mathrm{~g}$, solubility time of 35 seconds, viscosity $1.75 \mathrm{MPa} . \mathrm{S}$, water content $1.19 \%$, ash content $3.10 \%$, and $\mathrm{pH}=5.1$.

\section{ACKNOWLEDGMENTS}

We thank the ISDB Project of Jember University for funding this research through a food security consortium research grant IDB Project Contract Number : 268/UN25.7/PIU-IDB/2019.

\section{REFERENCES}

1. G.E. Amidon, in R.C. Rowe, P.J. Sheskey, M.E. Quinn (Eds), Citric Acid Monohydrate, Sixth Edition, Handbook of Pharmaceutical Excipients, 96, 1053-1068 (2009)

2. H.C. Ansel, Pengantar Bentuk Sediaan Farmasi, transleted by F. Ibrahim. (Ed) IV. 605-619 (Jakarta, UI Press, 2005)

3. G.S. Banker, N.R. Anderson, Tablet In the Theory and Practice of Industrial Pharmacy, Ed III, Translated by Siti Suyatmi (UI Press, Jakarta, 1994)

4. Hernani, M. Raharjo, Tanaman Berkhasiat Antioksidan, Cetakan I, (Penebar Swadaya, Jakarta, 2005)

5. R. Juwita, Ensiklopedia Biologi: Tanaman Obat I. (Depok, Penebar Swadaya, 2008)

6. H.A. Lieberman, L. Lachman, J.B. Schwartz, Pharmacheutical Dosage Form Tablet, Vol 1 (Marcel Dekker Inc., New York, 1989)

7. R. Mohrle, Effervescent Tablets, In H.A. Lieberman, H.A. Lachman, J.B.Schwartz, (ed), Pharmaceutical Dosage Forms Tablets, Vol. I, 2thEd, Marcel Dekker Inc, New York, 225255(1989)

8. T.Y.Osawa, Y. Sugiyama, M. Inayoshi, S. Kawakishi, Antioxidative Activity of Tetrahydrocurcuminoids, Biosci.Biotech.Biochem, 59:16091612 (1995)

9. I. Paryanto, B. Srijanto, Ekstraksi Kurkumin Dari Temulawak (Curcuma xanthorriza Roxb.) Secara Perkolasi Dengan Pelarut Etanol, Jurnal Ilmu Kefarmasian Indonesia, 4, 74-77 (2006)

10. C.J.P.Siregar, S. Wikarsa, Teknologi Farmasi Sediaan Tablet Dasar-Dasar Praktis, Penerbit Buku Kedokteran EGC, jakarta, 54-55(2010)

11. T.N.S. Sulaiman, Teknologi dan Formulasi Sediaan Tablet, Pustaka Laboratorium Teknologi Farmasi, Fakultas Farmasi, Universitas Gadjah Mada, Yogyakarta. 56 - 59, 198 - 215 (2007)

12. F.G. Winarno, Kimia Pangan dan Gizi, Gramedia (2008).

13. Novidiyanto, A. Setyowati, Formulasi Serbuk Effervescent Sari Wortel (Daucus carrota), Agritech, Vol. 28, 4 (2008)

14. C.J.P. Siregar, Teknologi Farmasi Sediaan Tablet, Penerbit Buku Kedokteran, Jakarta (2010)

15. E.S. Syamsul, Supomo, Formulasi Serbuk Effervescent Ekstrak Air Umbibawang Tiwai (Eleuterine palmifolia) Sebagai Minuman Kesehatan, Trad. Med.J., Vol 19(3) (2014)

16. AOAC, Official Methods of Analysis of AOAC International $\left(19^{\text {th }} \mathrm{ed}\right)$, AOAC International Press, Maryland (2012)

17. Ansar, B. Rahardjo, Z. Noor, Rochmadi, Optimasi Teknik Pembuatan Tablet Effervescent Sari Buah Dengan Response Surface Method (RSM), J.Teknol. dan lndustri Pangan 20(1) : 25-31(2009) 
18. Ansar, Optimasi Formula dan Gaya Tekan Terhadap Tekstur dan Kelarutan Tablet Effervescent Buah Markisa, Jurnal Teknologi Pertanian 12(2) : 109-114 (2011)

19. H.C. Ansel, Pengantar Bentuk Sediaan Farmasi. Terjemahan : Farida lbrahim. Edisi IV. Ul Press. Jakarta (1989)

20. A.F. Marais, M. Song, M.M. Villiers, A Study of Powder Adhesion to Metal Surface During Compression of Effervescent Pharmaceutical Tablets. Journal of Pharmaceutical Pharmacology, 38(4): 489-493 (2003)

21. A. Sopian, R. Thahir, T.R. Muchtadi, Pengaruh Pengeringan Dengan Far Infrared Dryer, Oven Vakum dan Freeze Dryer Terhadap Warna, Kadar Total Karoten, Beta Karoten dan Vitamin C Pada Daun Bayam (Amaranthus tricolor L.). Jurnal Teknologi dan Industri Pangan. 16(2) : 133141(2005)

22. C.J.P. Siregar, S. Wikarsa, Teknologi Farmasi Sediaan Tablet, 145-177, Penerbit Buku Kedokteran EGC, Jakarta (2010)

23. S. Debnath, Effect of Processing Induced Transitions on the Dissolution Rate of Drugs with Low Aqueous Solubility, University of Minnesota (2003)

24. J.B. Hutchings, Food Color and Appearance, Springer, New York (1999)

25. A. Fudholi, Metode Kompresi dan Komposisi Direct, Majalah Medika No.7, Grafiti Medika Press (1983)

26. T.Estiasih, K. Ahmadi, Teknologi Pengolahan Pangan, Bumi Aksara, Jakarta (2009). 